\title{
THE COMBINATORIAL EFFECTS OF Azadirachta indica LEAF EXTRACTS WITH AMIKACIN AND TETRACYCLINE AGAINST CLINICALLY IMPORTANT BACTERIA
}

\author{
L.A. Sivasamugham*, K. Tze Sin, K. Thrumaran, G. Subramaniam \\ Faculty of Health and Life Sciences, INTI International University, Persiaran Perdana BBN, Putra Nilai, 71800 Nilai, Negeri Sembilan, Malaysia
}

Received - July 18, 2020; Revision - September 17, 2020; Accepted - December 08, 2020

Available Online - March 25, 2021

DOI: http://dx.doi.org/10.18006/2021.9(Spl-1-GCSGD_2020).S133.S138

\section{Keywords}

Neem leaf extract

Amikacin

Tetracycline

Antimicrobial

Synergistic

Antagonistic

\begin{abstract}
Antibiotic-resistance is a major threat in the treatment of diseases caused by resistant bacteria. Combination of plant extracts with antibiotics can serve as an alternative to antibiotics. Azadirachta indica (neem plant) has many antimicrobial properties due to the presence of secondary metabolites such as alkaloids and flavonoids. In this study, the combinatorial effects of neem leaf extracts with amikacin and tetracycline against eight clinically important gram-positive and gram-negative pathogens were investigated using the agar well diffusion assay. Synergistic effect of neem leaf extract and tetracycline was observed against Propionibacterium acnes, Bacillus subtilis, and S. pneumoniae with a significant enlargement $(\mathrm{p}<0.05)$ in the diameter of the zone of inhibition. However, the same combination showed insignificant inhibition against $S$. faecalis, Staphylococcus epidermidis, Enterococcus faecalis, and Staphylococcus aureus. The neem leaf extract-amikacin combination showed insignificant antibacterial activity against Staphylococcus aureus, S. epidermidis, S. pneumoniae, and Pseudomonas aeruginosa. An antagonistic effect was observed when Bacillus subtilis was exposed to the same combination as there was a significant reduction $(\mathrm{p}<0.05)$ in the zone of inhibition. This study suggests the potential development of the neem leaf extract-tetracycline combination as an antibacterial agent against $P$. acnes, $B$. subtilis, and $S$. pneumoniae. However, this preliminary data requires further investigation and test on a wider range of clinical isolates to make a more decisive conclusion. The antagonistic effect of the neem leaf extract and amikacin suggests that the individual agents are potent as antibacterial agents than the combination.
\end{abstract}

* Corresponding author

E-mail: lalitaa.sivasamugham@newinti.edu.my (Lalita Ambigai Sivasamugham)

Peer review under responsibility of Journal of Experimental Biology and Agricultural Sciences.

Production and Hosting by Horizon Publisher India [HPI] (http://www.horizonpublisherindia.in/).

All rights reserved.
All the articles published by Journal of Experimental Biology and Agricultural Sciencesare licensed under a Creative Commons Attribution-NonCommercial 4.0 International License Based on a work at www.jebas.org.

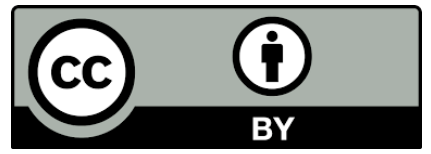




\section{Introduction}

Antibiotic resistance is an emerging global health threat (WHO, 2020). The increase of antibiotic resistance urges the need to discover and develop alternative antimicrobial agents from other potential sources including plants (Othman et al., 2019). The use of medicinal plants in treatment has been recorded since ancient history (Petrovska, 2012). Studies show that about $80 \%$ of the global population use plants for their primary health care (Ekor, 2014). The medicinal plants such as Allium sativum (garlic) and Prosopis juliflora (mesquite) contain phytoconstituents such as alkenyl phenols, alkaloids, and flavonoids that have antimicrobial properties (Emad, 2011). Plant extracts also generally show no or very low toxic effects (Cowan, 1999). Also, the cost of production is low (Teka et al., 2015; Cheesman et al., 2017).

Azadirachta indica is widely used as a traditional medicine due to its antimicrobial and other medicinal properties. Studies show antimicrobial activities of the different parts of the neem plant (Raja Ratna Reddy et al., 2013). A combination of neem leaves extracts with other medicinal plants exhibited synergistic antibacterial effects against Pseudomonas aeruginosa, S. mutans, S. gordonii, and Candida albicans (Bhuva \& Dixit, 2015; Saini et al., 2020). Thus, this study was aimed to investigate the combinatorial effects of $A$. indica leaf extract with amikacin and tetracycline against eight clinically important bacteria using the agar well diffusion assay apart from the qualitative screening of the phytochemicals in the leaf extract.

\section{Materials and Methods}

\subsection{Pure Culture Isolation}

The bacterial cultures used in this study were Streptococcus faecalis, Enterococcus faecalis, S. aureus, S. epidermidis, Propionibacterium acnes, Bacillus subtilis, Serratia marcescens, and Pseudomonas aeruginosa. These cultures were in glycerol stock and were obtained from the culture collections of INTI International University. All bacterial cultures were inoculated onto nutrient agar and incubated at $37^{\circ}$ for $24 \mathrm{~h}$ to obtain homogenous colonies.

\subsection{Confirmatory Tests}

The pure cultures were Gram-stained using the method described by Moyes et al. (2009). The Gram-positive bacteria were subjected to catalase test as described by Iwase et al. (2013) and grown on mannitol salt agar. The IMVIC (Indole, methyl red, VogesProskauer, and Citrate) test, oxidase test, and the triple sugar iron test was used to confirm the identity of the Gram-negative bacteria (Holt, 1994; Cappuccino \& Sherman, 2005).

\subsection{Ethanolic A. indica Extract Preparation}

Fresh neem leaves were obtained from a residential garden in Seremban, Malaysia. The leaves were rinsed in the following order; water, $80 \%$ (v/v) ethanol, and sterile deionized water (Noor et al., 2011). The dust-free neem leaves were sun-dried for 24-48 $\mathrm{h}$, ground using a micro-fine multipurpose powder dry medicine blender (Himitzu), and sieved with a 40-mesh sieve. The neem leaf powder $(35 \mathrm{~g}$ ) was suspended into $70 \mathrm{~mL}$ of $80 \%$ (v/v) ethanol to a ratio of 1:2. The mixture was incubated in an orbital shaker at room temperature for $24 \mathrm{~h}$ and centrifuged at $10,000 \mathrm{rpm}$ for 15 min at room temperature (Itelima et al., 2016). The supernatant was filter-sterilized $(0.2 \mu \mathrm{m})$ and analyzed for its phytoconstituents before subjecting to the agar well diffusion assay (Echegoyen et al., 2015).

\subsection{Agar Well Diffusion Assay}

The antibacterial activities of the leaf extracts were detected using the agar well diffusion assay (Perez et al., 1990). The overnight bacterial cultures which were adjusted to $0.5 \mathrm{McF}$ arland standard was lawned onto $\mathrm{MH}$ agar using a sterile wooden applicator. Four wells were made onto the agar by puncturing the agar using a sterile micropipette tip. Wells in quadrants 1 and 2 were filled with $200 \mu \mathrm{L}$ of neem extracts $(0.5 \mathrm{~g} / \mathrm{mL})$ and $200 \mu \mathrm{L}$ of antibiotics respectively (Clinical Laboratory Standard Institute, 2017). Quadrant III was filled with $200 \mu \mathrm{L}$ of $80 \%$ (v/v) ethanol whereas; Quadrant IV had $200 \mu \mathrm{L}$ of neem extract $(0.5 \mathrm{~g} / \mathrm{mL})$ and antibiotic combination. The agar was incubated at $37^{\circ} \mathrm{C}$ for 24 hours. This assay was done in triplicates. The effects of the neem leaf extractantibiotic combinations were analyzed by measuring the diameter of the zone of inhibition (in $\mathrm{mm}$ ) using a metric ruler.

\subsection{Qualitative Phytochemical Screening}

The ethanolic neem leaf extracts were screened for phytochemicals using previously described methods to Shu'aibu et al. (2015).

\subsection{Statistical Analysis}

ANOVA in IBM SPSS Statistics Version 22 was used to determine the significant differences between the neem leaf extracts, antibiotics, and the neem leaf-antibiotic combination when tested against different bacterial strains with a significant value of $\mathrm{p}<0.05$.

\section{Results and Discussion}

Amikacin is a semi-synthetic aminoglycoside used against a wide spectrum of Gram-negative bacteria, such as Serratia spp. and $P$. aeruginosa as well as Gram-positive bacteria, such as Staphylococcus (eMC, 2020). Tetracycline is a polyketide 
antibiotic that is effective against both Gram-positive and Gramnegative bacteria (Eliopoulos \& Roberts, 2003).

The combinatorial effect of neem leaf extract with tetracycline showed a significantly larger zone of inhibition $(\mathrm{p}<0.05)$ compared to the individual applications of neem leaf extract and tetracycline against $P$. acnes, B. subtilis, and $S$. pneumoniae (Figure 1). This indicates the synergistic effect of the neem leaf extract-tetracycline combination against these bacteria. This finding agrees with the study by Rasha et al. (2015) that showed the synergistic effect of $V$. nilotica and $S$. alexandrina leaf extract-tetracycline combination against $B$. subtilis with a significant increase in the diameter of the zone of inhibition. Kusum \& Sharmita (2015) also reported the synergistic effect of neem leaf extract against E. coli when combined with tetracycline. The synergistic activity of the neem leaves extract-tetracycline observed in this study could have been attributed to the bioactive phytoconstituents of the neem leaf extract that enhanced the antibacterial activity of tetracycline (Aslam et al., 2009). Sibanda \& Okoh (2007) suggested that bioactive phytoconstituents could inhibit the activity of the efflux pumps in bacteria. Efflux pump is a transport protein found in Gram-positive and Gram-negative bacteria that extrudes toxic compounds such as antibiotics out of the bacterial cells, making the cells to resist the action of antibiotics (Webber \& Piddock, 2003). The inhibition of the efflux pump activity increases the entry of antibiotics into bacterial cells enabling them to reach the target site and destroy the cells (Lomovskaya \& Bostian, 2006). Efflux pump inhibitors such as ferruginol isolated from Chamaecyparis lawsoniana inhibited the tetracycline-resistant efflux pump, quinolone-resistant efflux pump, and erythromycinresistant efflux pump in $S$. aureus which improved the antimicrobial effect of tetracycline, quinolone, and erythromycin respectively (Aiyegoro et al., 2011).

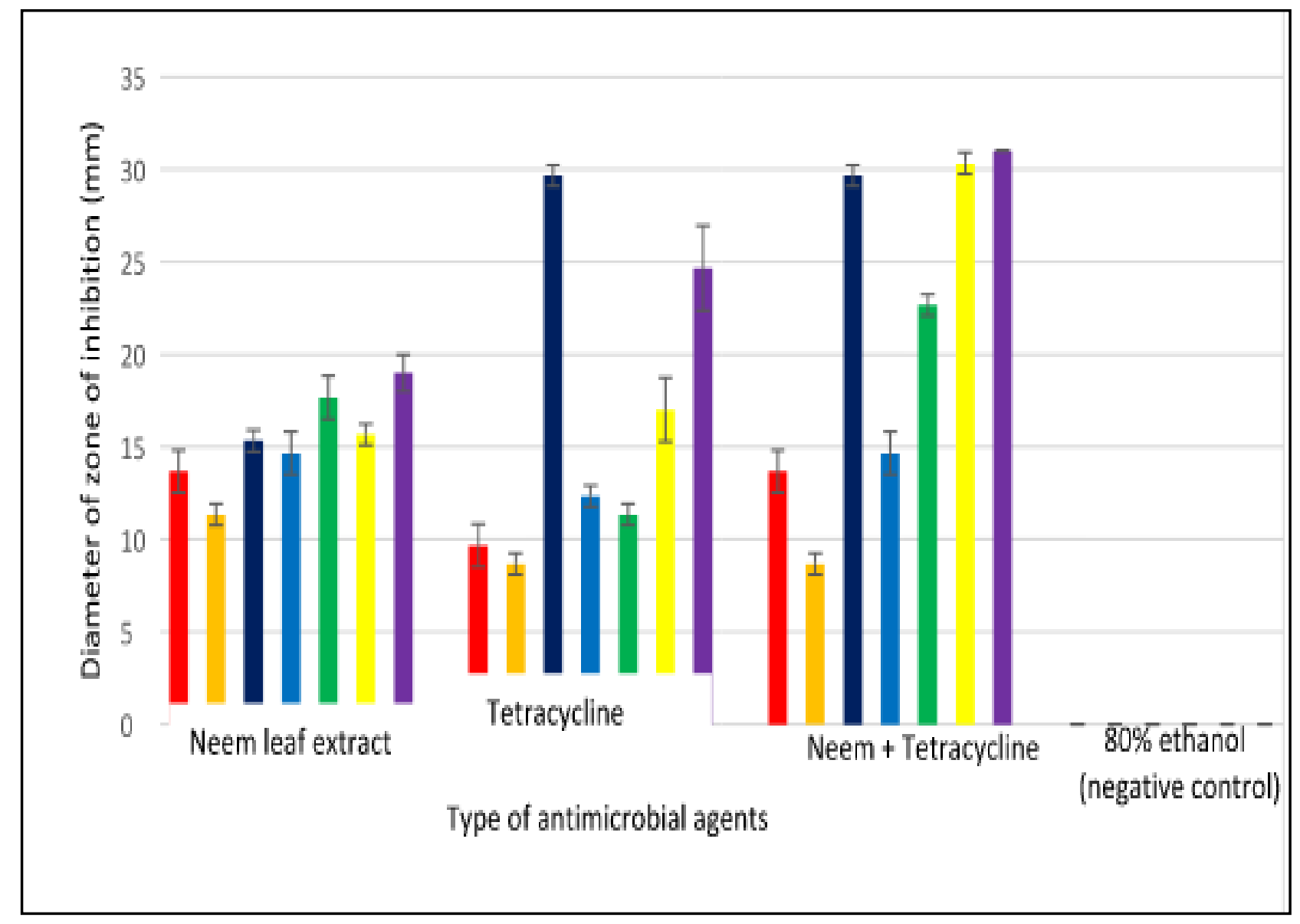

Figure 1 The mean diameter of zone of inhibition $(\mathrm{mm})$ produced by neem leaf extract, tetracycline and combination of neem leaf extract with tetracycline against the tested bacteria

Journal of Experimental Biology and Agricultural Sciences http://www.jebas.org 
Qualitative phytochemical screening of the neem leaf extract showed the presence of glycosides, alkaloids, phytosterols, and flavonoids (Table 1) and this was consensus with the findings by Pandey et al. (2014) and Al-Hashemi \& Hossain (2016). These phytochemicals could have exhibited a concerted effect eventually causing $P$. acnes, B. subtilis and $S$. pneumoniae to be more permeable to the action of tetracycline.

Table 1.Qualitative Phytochemical screening of neem leaf extract

\begin{tabular}{|cc|}
\hline Phytochemicals & Ethanolic Extract \\
\hline Alkaloids & $\mathrm{X}$ \\
\hline Flavonoids & $\mathrm{X}$ \\
\hline Glycosides & $\mathrm{X}$ \\
\hline Phytosterols & $\mathrm{X}$ \\
\hline Saponins & $\mathrm{O}$ \\
\hline
\end{tabular}

Here $\mathrm{X}$ indicates presence and $\mathrm{O}$ indicates the absence of the specified phytochemicals in the leaf extract

Flavonoids are suggested to inhibit bacterial growth by inhibiting nucleic acid synthesis, plasma membrane function apart from inhibiting the activity of porin on the bacterial cell membrane. Flavonoids could have also altered the bacterial membrane permeability causing the cells to be more susceptible to the action of tetracycline (Xie et al., 2015). Alkaloids present in the neem leaf extract could have inhibited the efflux pump actions in the tested bacteria as reported by Mabhiza et al. (2016).
Another possible reason for the synergistic effect is the bacterial protein synthesis inhibition that resulted in a potent tetracycline activity (Aiyegoro et al., 2011). In this study, the qualitative preliminary phytochemical screening showed the presence of glycosides, alkaloids, phytosterols, and flavonoids but a quantitative analysis will identify the exact components that exhibited the synergistic activity with tetracycline. The findings in this study strongly suggest the potential use of the neem leaf extract-tetracycline combination as an effective antibacterial agent against $P$. acnes, B. subtilis, and $S$. pneumoniae. The combination might reduce the development of tetracycline-resistant bacteria and reduce the dose of tetracycline required to treat infections caused by these bacteria. However, further investigation and tests on different strains of P. acnes, B. subtilis, and S. pneumoniae are required before a more decisive conclusion can be made.

The combination of neem leaf extract and tetracycline showed no difference in the inhibition against $S$. aureus, S. epidermidis, $S$. faecalis, and E. faecalis (Figure 1). This might be due to the MIC of the combination of neem leaf extract and tetracycline that was not potent enough to inhibit the bacterial activity (Aiyegoro et al., 2011). Apart from that, the genetic variation in neem plant and bacteria might reduce the effectiveness of antimicrobial activity of neem leaf due to the expression of a certain gene in bacteria that could alter or destroy the antimicrobial molecules found in the extract (Muniata \& Arias, 2016). However, the mode of action and mechanisms of active phytoconstituents of the neem leaf extract has to be studied to have a greater insight on this.

The neem leaf extract-amikacin combination showed a significant reduction $(\mathrm{p}<0.05)$ in the diameter of the zone of inhibition against B. subtilis indicating an antagonistic effect (Figure 2).

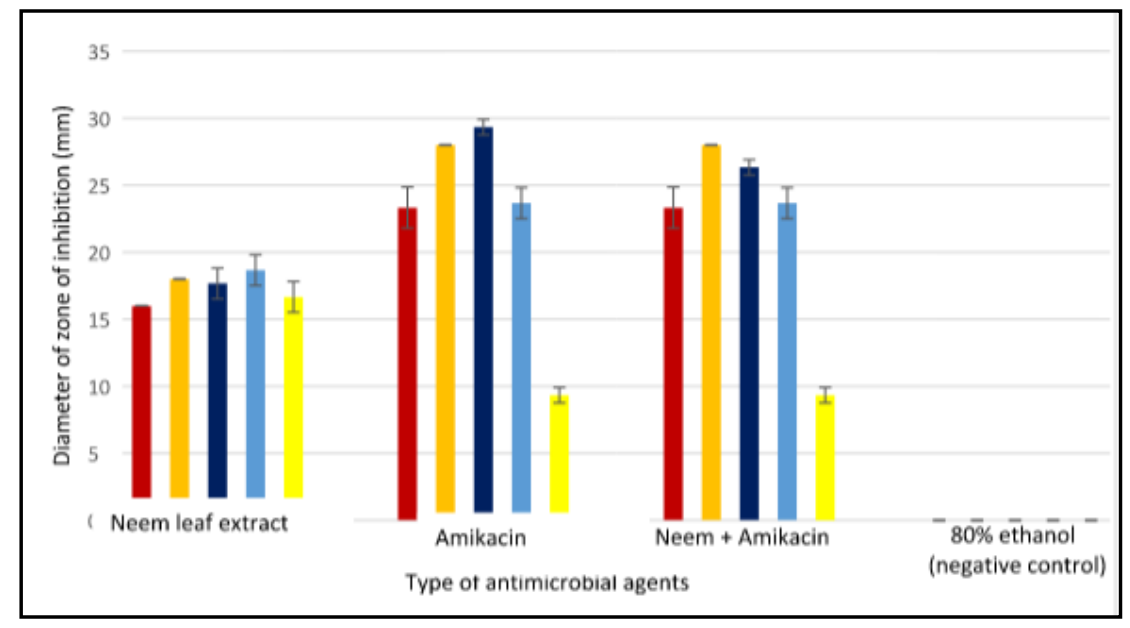

Figure 2 The mean diameter of zone of inhibition $(\mathrm{mm})$ produced by neem leaf extract, amikacin, and combination of neem leaf extract with amikacin against the tested bacteria 
This antagonistic effect might be due to the presence of certain phytoconstituents in the extract that had competitive binding with amikacin to the bacterial membrane hence reducing its antibacterial activity (Passat, 2012; Eze et al., 2013). The antagonistic effect between neem leaf extract and amikacin indicates that amikacin should be used individually as the combination showed reduced activity and possibly an adverse effect.

The combinatorial effect of neem leaf extract and amikacin against $S$. aureus, S. epidermidis, S. pneumoniae, and P. aeruginosa showed no significant difference in the diameter of the zone of inhibition indicating that the combination had no synergistic or antagonistic effect against these bacteria. Similar findings were reported by El-Zawahry et al. (2013) where the combinatorial effect of tamarind extract with amikacin showed a similar diameter of zone of inhibition with amikacin. This might be due to the absence of interaction between phytoconstituents of the neem leaf extract and amikacin (Bhuva \& Dixit, 2015). This indicates that it is not crucial to combine neem leaf extract and amikacin for therapeutic purposes. However, to date, no study had been done on the combinatorial effect of neem leaf extract and amikacin against the bacteria used in this study. Hence, further investigations must be done to make a more decisive conclusion.

\section{Conclusion}

The combination of neem leaf extract with tetracycline showed synergism against $P$. acnes, B. subtilis, and $S$. pneumoniae based on the zone of inhibition suggesting the potential combination to treat related infections. Antagonistic effect exerted by amikacin and neem leaves extracts combination against $B$. subtilis suggests that they should not be combined. However, these are preliminary findings and thus require further investigation and test on a wider range of clinical isolates to make a more decisive conclusion on the potential use of neem leaf extract with tetracycline and amikacin.

\section{Acknowledgements}

The authors wish to acknowledge INTI's Final Year Project Funding by INTI International University.

\section{Conflict of interest}

The authors declare that they have no conflict of interest.

\section{References}

Aiyegoro O, Adewusi A, Oyedemi S, Akinpelu D, Okoh A (2011) Interactions of antibiotics and methanolic crude extracts of Afezelia africana (Smith.) against drug resistance bacterial isolates. International Journal of Molecular Science 12 (7): 4477-4503.
Al-Hashemi ZSS, Hossain MA (2016) Biological activities of different neem leaf crude extracts used locally in Ayurvedic medicine. Pacific Science Review A: Natural Science and Engineering 18(2): 128-131.

Aslam F, Rehman KU, Asghar M, Sarwar M (2009) Antibacterial activity of various phytoconstituents of neem. Pakistan Journal of Agricultural Sciences 46 (3): 209-213.

Bhuva RM, Dixit YM (2015) Comparative antimicrobial activities of neem and curry leaf extracts and their synergistic effect against selected pathogenic bacteria and fungi. International Research Journal of Pharmacy 6 (11): 755-759.

Cappuccino JG, Sherman N (2005) Microbiology a laboratory manual. Benjamin Cummings: New York 125-79.

Cheesman MJ, Ilanko A, Blonk B, Cock IE (2017) Developing new antimicrobial therapies: are synergistic combinations of plant extracts/compounds with conventional antibiotics the solution?. Pharmacognosy Reviews 11 (22): 57.

Clinical and Laboratory Standards Institute (2017) Performance standards for antimicrobial susceptibility testing (M100) (27th ed.). Pennsylvania, USA: Clinical and Laboratory Standard Institute.

Cowan MM (1999) Plant products as antimicrobial agents. Clinical Microbiology Reviews 12 (4): 564-582.

Echegoyen CG, Pacheco RP, Aguilera AA, Rivera LL, Hernandez NA and Martinez EC (2015) Effects of aqueous and ethanol extract of dried leaves of Pseudocalymma alliaceum (Bignonaceae) on haematological and biochemical parameters of wistar rats. Asian Pacific Journal of Reproduction 4 (2): 129-134.

Ekor M (2014) The growing use of herbal medicines: issues relating to adverse reactions and challenges in monitoring safety. Frontiers in Pharmacology 4: 177.

Eliopoulos GM, Roberts MC (2003) Tetracycline Therapy: Update. Clinical Infectious Diseases 36 (4): 462-467.

El-Zawahry YA, Reda FM, Azazy WM (2013) Synergistic Effect of Combination Treatment by Certain Plant Extracts and Some Antibiotics on the Resistance of Pathogenic Bacteria to Some Common Antibiotics. Life Science Journal 10 (4): 3477-3489.

Emad MA (2011) Plants: an alternative source of antimicrobials. Journal of Applied Pharmaceutical Science 1(6): 16-20.

eMC (2015) Amikacin $250 \mathrm{mg} / \mathrm{ml}$ Injection, retrieved from https://www.medicines.org.uk/emc/product/3784/smpc\#gref on 15.12.2020. 
Eze EA, Oruche NE, Eze CN (2013) Interaction of the extracts of three medicinal plants with antibiotics against some antibiotic resistant bacteria. Academic Journals 8 (28): 1360-1367.

Holt JH (1994) Bergey's Manual of Determinative Bacteriology, 9th edition”, Lippincott Williams \& Wilkins, Philadelphia.

Itelima JU, Nwokedi VC, Ogbonna AI, Nyam MA (2016) Phytochemical screening and antimicrobial activity evaluation of aqueous and ethanolic extracts of the leaf of Azadirachta indica Juss (neem) on some microorganisms. World Journal of Microbiology 3 (1): 56-60.

Iwase T, Tajima A, Sugimoto S, Okuda K, Hironaka I, Kamata Y, Takada K, Mizunoe Y (2013) A simple assay for measuring catalase activity: a visual approach. Scientific Reports 3: 3081.

Kusum L, Sharmita G (2015) Synergistic effect of Azadirachta indica L., Aloe vera L. and antibiotics against E. coli bacterium. International Journal of Pharmaceutical Research and Bio-Science 4 (2): 291-304.

Lomovskaya O, Bostian KA (2006) Practical applications and feasibility of efflux pump inhibitors in the clinic-A vision for applied use. Biochemical Pharmacology 71 (7): 910-918.

Mabhiza D, Chitemerere T, Mukanganyama S (2016) Antibacterial Properties of Alkaloid Extracts from Callistemon citrinus and Vernoniaadoensis against Staphylococcus aureus and Pseudomonas aeruginosa. International Journal of Medicinal Chemistry 1: 1-7.

Moyes RB, Reynolds J, Breakwell DP (2009) Differential staining of bacteria: Gram stain. Current Protocols in Microbiology 15 (1): A.3C.1-A.3C.8.

Munita JM, Arias CA (2016) Mechanisms of antibiotic resistance. Microbiology Spectrum 4 (2): 481-511.

Noor AA, Memon AG, Sherwani SK (2011) Dose response curve of plant extracts against the human pathogens. Gomal University Journal of Research 27 (2): 1-17.

Othman L, Sleiman A, Abdel-Massih RM (2019) Antimicrobial activity of polyphenols and alkaloids in middleeastern plants. Frontiers in Microbiology, 10: 911.

Pandey G, Verma KK, Singh M (2014) Evaluation of phytochemical, antibacterial and free radical scavenging properties of Azadirachta indica (neem) leaves. International Journal of Pharmacy and Pharmaceutical Sciences 6 (2): 444-447.

Passat DN (2012) Interaction of Black and Green Tea Water Extracts with Antibiotics Activity in Local Urinary Isolated Escherichia coli. Journal of Al-Nahrain University 15 (3): 134-142.
Perez C, Pauli M, Bazerque P (1990) An antibiotic assay by the well agar method. ActaBiologiae et Medicinae Experimentalis 15: 113-115.

Petrovska BB (2012) Historical review of medicinal plants' usage. Pharmacognosy Reviews 6(11): 1-5.

Raja Ratna Reddy Y, Krishna Kumari C, Lokanatha O, Damodar Reddy C (2013) Antimicrobial activity of Azadirachta indica (neem) leaf, bark and seed extracts. International Journal of Research in Phytochemistry and Pharmacology 3 (1): 1-4.

Rasha A, Saiym A, Hatil HAK, Magboul AZA (2015) Synergistic Antibacterial Interaction between Trachyspermum ammi, Senna alexandrina Mill and Vachellia nilotica spp. Nilotica Extract and Antibiotics. Pakistan Journal of Biological Sciences 18: 115-121.

Saini A, Saini G, Singh B, Vyas M, Verma S, Prakash O (2019) Synergestic effect of Azadirachta indica and Curcuma longa with fluconazole gel against Candida albicans. International Journal of Pharmaceutical Sciences and Research 10 (2): 692-700.

Shu'aibu I, Hamman JB, Goje LJ, Mu'inat AM, Jauro HA, Kabiru MY (2015) Phytochemical analysis and evaluation of bacteriostatic effect of neem (Azadirachta indica) leaves on some clinical bacterial isolates. Journal of Harmonized Research in Applied Sciences 3 (3): 152-157.

Sibanda T, Okoh AI (2007) The challenges of overcoming antibiotic resistance: Plant extracts as potential sources of antimicrobial and resistance modifying agents. African Journal of Biotechnology 6 (25): 2886-2896.

Teka A, Rondevaldova J, Asfaw Z, Demissew S, Damme PV, Kokoska L, Vanhove W (2015) In vitro antimicrobial activity of plants used in traditional medicine in Gurage and Silti Zones, South Central Ethiopia. BMC Complementary and Alternative Medicine 15: 286.

Webber MA, Piddock LJV (2003) The importance of efflux pumps in bacterial antibiotic resistance. Journal of Antimicrobial Chemotherapy 51 (1): 9-11.

WHO, "Antibiotic Resistance", (2020) retrieved from https://www.who.int/news-room/fact-sheets/detail/antibioticresistance, and on 15.12.2020.

Xie Y, Yang W, Tang F, Chen X, Ren L (2015) Antibacterial activities of flavonoids: structure-activity relationship and mechanism. Current medicinal chemistry 22(1): 132-149. 